\title{
Neutrophil Activation and Erythrocyte Membrane Protein Composition in Stage 5 Chronic Kidney Disease Patients
}

\author{
Elísio Costa ${ }^{1,2}$, Luís Belo ${ }^{2,3}$ and Alice Santos-Silva2,3 \\ ${ }^{1}$ Instituto de Ciências da Saúde da Universidade Católica Portuguesa \\ 2Instituto de Biologia Molecular e Celular da Universidade do Porto \\ ${ }^{3}$ Faculdade de Farmácia da Universidade do Porto \\ Portugal
}

\section{Introduction}

Anaemia is a frequent complication associated with stage 5 chronic kidney disease (CKD), and is mainly due to insufficient production of erythropoietin by the kidneys. Accumulation of uremic toxins, excessive toxic storage of aluminium in the bone marrow (Miyoshi, 2006), blood loss (either iatrogenic, from the puncture sites of the vascular access and blood sampling, or from other sources, such as the gastrointestinal tract), and premature erythrocyte destruction have also been frequently associated with anaemia in stage 5 CKD patients (Medina, 1994; Pisoni, 2004).

The erythrocyte, presenting a limited biosynthesis capacity, suffers and accumulates physical and/or chemical changes, which become more pronounced with cell aging, and whenever an unusual physical or chemical stress develops (Locatelli, 2004a). Erythrocytes are physically stressed during the haemodialysis process, and metabolically stressed by the unfavourable plasmatic environment, due to metabolite accumulation, and by the high rate of haemoglobin autoxidation, due to the increase in haemoglobin turnover, a physiologic compensation mechanism triggered in case of anaemia (Lucchi, 2000; Stoya, 2002). The erythrocytes are, therefore, continuously challenged to sustain haemoglobin in its reduced functional form, as well as to maintain the integrity and deformability of the membrane.

Leukocytosis is essential as the primary host defence, and neutrophils, the major leukocyte population of blood in adults, play a primordial role. It is well known that neutrophils have mechanisms that are used to destroy invading microorganisms. These cells use oxygen-dependent and oxygen-independent microbicidal artillery to destroy and remove infectious agents (Witko-Sarsat, 2000). Activated neutrophils also undergo degranulation, with the release of several components, namely, proteases and cationic proteins (Witko-Sarsat, 2000).

In this book chapter we review the cross-talk between changes in erythrocyte membrane protein composition and the release of neutrophil activation products. 


\section{Erythrocyte membrane protein composition}

Erythrocyte membrane proteins can be classified into three categories, according to their functional properties in the membrane struture (An \& Mohandas, 2008; Mohandas \& Gallagher, 2008). The first includes cytoskeletal proteins, as spectrin ( $\alpha$ and $\beta$ chains), protein 4.1, and actin; the second includes integral/transmembrane proteins of which the representative proteins are band 3 and glycophorins; the third includes anchoring/linker proteins, namely, ankyrin (also known as band 2.1) and protein 4.2. The anchoring/linker membrane proteins mediate the attachment of cytoskeletal proteins to integral proteins (Fig. 1) (Lucchi, 2000; Gallagher, 2005; Mohandas \& Gallagher, 2008).

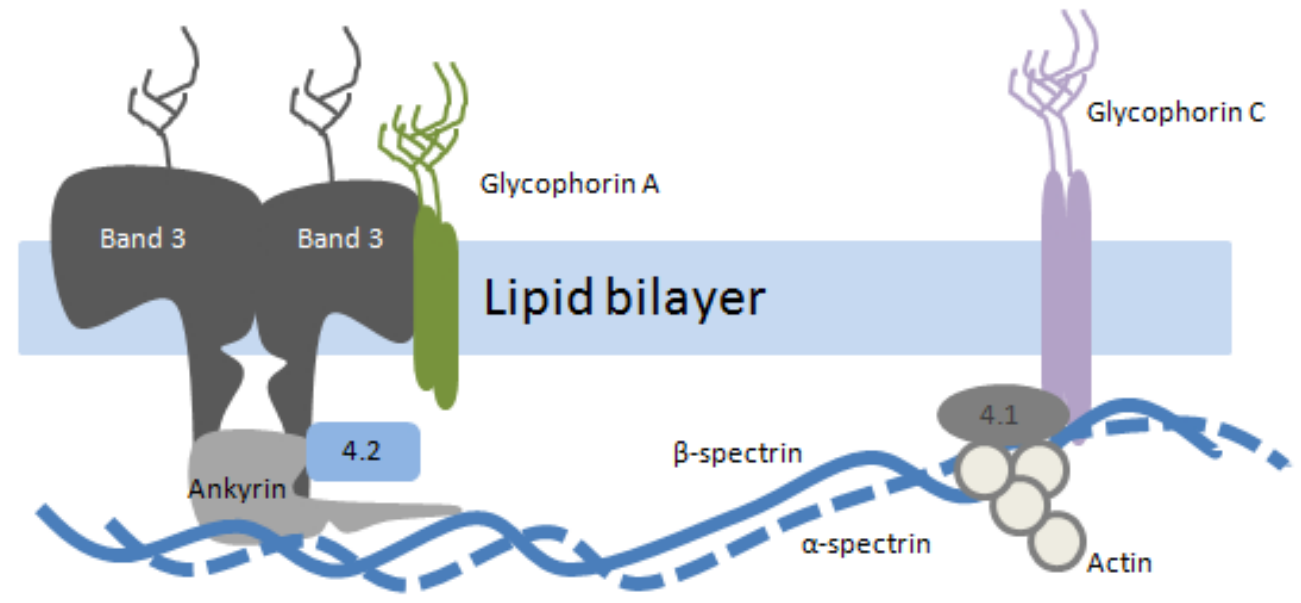

Fig. 1. Schematic representation of red blood cell membrane, showing the topographical localization of proteins and their interactions. The membrane is a complex structure in which a plasma membrane envelope composed of amphiphilic lipid molecules is anchored to a two dimensional elastic network of skeletal proteins through tethering sites (transmembrane proteins) embedded in the lipid bilayer. Adapted from An \& Mohandas, 2008.

The cytoskeleton is a 3-dimensional network of proteins that covers the cytoplasmatic surface of the erythrocyte membrane and is responsible for its biconcave shape and the properties of elasticity and flexibility. It comprises approximately half the membrane protein mass and is primarily composed of spectrin, protein 4.2 and actin. Spectrin is the major protein of the cytoskeleton, and, therefore, the primary cause of erythrocyte shape, integrity and deformability. It is linked to the lipid bilayer, by vertical protein interactions with the transmembrane proteins, band 3 and glicophorin A (Lucchi, 2000). In the vertical protein interaction of spectrin with band 3 there are also ankyrin (also known as band 2.1) and protein 4.2 involved. A normal linkage of spectrin with the other proteins of the cytoskeleton assures normal horizontal protein interactions. The vertical and horizontal interactions between membrane constituents account for the integrity, strength, and deformability of the cell (An \& Mohandas, 2008; Mohandas \& Gallagher, 2008). Disruption of vertical interactions because of membrane protein deficiencies favours membrane vesiculation with loss of surface area and development of spherocytic cells, with increasing 
rigidity of the cell membrane that may lead to premature spleen sequestration and destruction (An \& Mohandas, 2008).

\section{Neutrophil activation}

Leukocytosis and recruitment of circulating leukocytes into the affected areas are hallmarks of inflammation. Leukocytes are chimio-attracted to inflammatory regions and their transmigration from blood to the injured tissue is primarily mediated by the expression of cell-adhesion molecules in the endothelium, which interact with surface receptors on leukocytes (Muller, 1999; Sullivan, 2000). This leukocyte-endothelial interaction is regulated by a cascade of molecular steps that lead to the morphological changes that accompany adhesion. At the inflammatory site, leukocytes release their granular content and may exert their phagocytic capacities.

In acute inflammation, the leukocyte infiltration is predominantly of neutrophils, whereas in chronic inflammation an infiltration predominantly of macrophages and lymphocytes is observed. Leukocyte-endothelial cell interactions are important for leukocyte transmigration and trafficking in physiological conditions. There is increasing evidences that changes in those leukocyte-endothelial interactions, due to endothelium damage or dysfunction, might be implicated in the pathogenesis of diseases, such as inflammatory diseases (Harlan, 1985; Ley, 2007).

Leukocytosis is essential as the primary host defence, and neutrophils, the major leukocyte population of blood in adults, play a primordial role. It is well known that neutrophils have mechanisms that are used to destroy invading microorganisms. These cells use an extraordinary array of oxygen-dependent and oxygen-independent microbicidal weapons to destroy and remove infectious agents (Witko-Sarsat, 2000). Oxygen-dependent mechanisms involve the production of reactive oxygen species (ROS), which can be microbicidal (Roos, 2003), and lead to the development of oxidative stress. Oxygen-independent mechanisms include chemotaxis, phagocytosis and degranulation. The generation of microbicidal oxidants by neutrophils results from the activation of a multiprotein enzyme complex, known as the reduced nicotinamide adenine dinucleotide phosphate (NADPH) oxidase, which catalyzes the formation of superoxide anion $\left(\mathrm{O}_{2}{ }^{-}\right)$. Activated neutrophils also undergo degranulation, with the release of several components, namely, proteases (such as elastase) and cationic proteins (such as lactoferrin) (Saito, 1993; Brinkmann, 2004).

Elastase is a member of the chymotrypsin superfamily of serine proteinases, expressed in monocytes and mast cells, but mainly expressed by neutrophils, where it is compartmentalized in the primary azurophil granules. The intracellular function of this enzyme is the degradation of foreign microorganisms that are phagocytosed by the neutrophil (Brinkmann, 2004). Elastase can also degrade local extracellular matrix proteins (such as elastin), remodel damaged tissue, and facilitate neutrophil migration into or through tissues. Moreover, elastase also modulates cytokine expression at epithelial and endothelial surfaces, up-regulating the production of cytokines, such as IL-6, IL-8, transforming growth factor $\beta$ (TGF- $\beta$ ) and granulocyte-macrophage colony-stimulating factor (GM-CSF); it also promotes the degradation of cytokines, such as IL-1, TNF- $\alpha$ and IL2. There is evidence in literature that high levels of elastase are one of the major pathological factors in the development of several chronic inflammatory lung conditions (Fitch, 2006). 
Plasma lactoferrin is predominantly neutrophil derived and its presence in the specific granules is often used to identify these types of granules. Lactoferrin is also found in other granules, in the tertiary granules, though in lower concentrations (Olofsson, 1977; Baynes 1986; Halliwell \& Gutteridge, 1990; Saito, 1993). Lactoferrin is a multifunctional iron glycoprotein, which is known to exert a broad-spectrum primary defence activity against bacteria, fungi, protozoa and viruses. It can bind to large amounts of free iron. The ironbound lactoferrin is taken up by activated macrophages, which express specific lactoferrin receptors. During inflammation, this contributes to iron deprivation of the erythroid precursors, which do not express lactoferrin receptors (Bárány, 2001). Other mechanisms in which lactoferrin is implicated include a growth regulatory function in normal cells, coagulation, and perhaps cellular adhesion modulation (Levay and Viljoen, 1995).

In a recent study of our group (Pereira, 2010), we found that stage 5 CKD patients present a decreased expression of the CXCR1 neutrophil surface marker, which plays an important role in neutrophil migration (Fig. 2); a higher elastase plasma levels was also found, as compared to a control group (table 1).
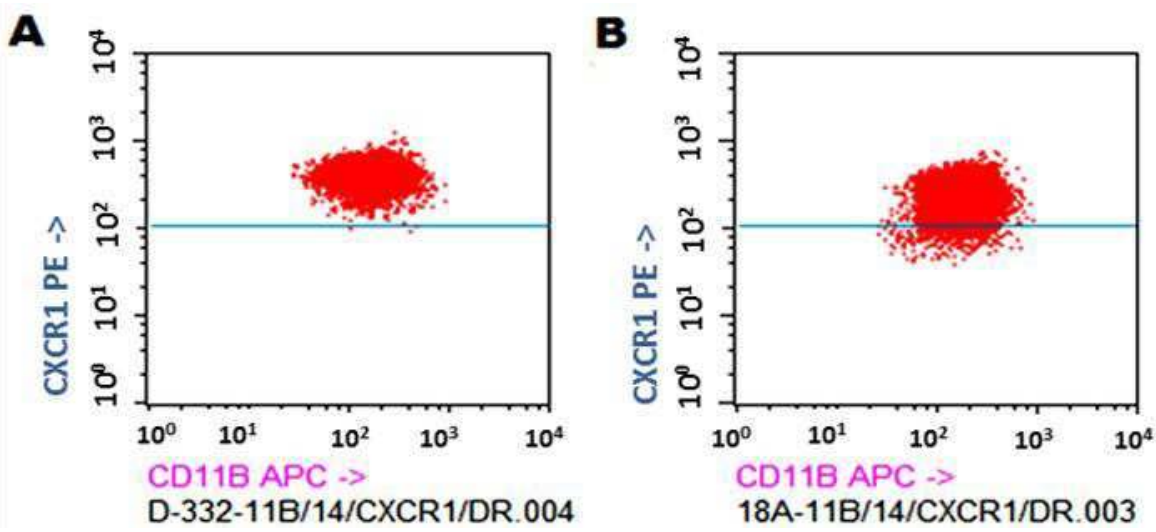

Fig. 2. Decreased expression of the CXCR1 neutrophil surface markers in stage 5 CKD patients. A - Control; B - Stage 5 CKD patient. Cells were stained with allophycocyanin (APC) conjugated anti-CD11B and phycoerythrin (PE) conjugated anti-CXCR1.

CXCR1 is a receptor that recognizes CXC chemokines, particularly, the pro-inflammatory IL-8 (Pay, 2006; Sherry, 2008). The decreased expression of this receptor in neutrophil surface is associated to the release of components of neutrophil granules and is correlated with the need for inotropic support. Recently, it was reported that the levels of the neutrophil chemoattractant receptor, CXCR1, is mildly diminished in CKD pediatric patients, as a consequence of the end stage renal disease itself, and that the recurrent serial bacterial infections they suffered was markedly exacerbated by CXCR1 neutrophil loss (Sherry, 2008). This loss of CXCR1 on neutrophils might be due to the uremic state, to changes in leukocyte adhesion molecule expression or membrane microvilli and/or to crossdesensitization of this receptor, due to prior exposure to several unrelated chemoattractants, including $\mathrm{N}$-formylated peptides and the complement cleavage product C5a (Sherry, 2008). Chronic exposure of circulating inflammatory cells to these mediators may lead to loss of chemokine receptor expression and/or function via cross-desensitization. 


\begin{tabular}{|l|c|c|}
\hline & $\begin{array}{c}\text { Controls } \\
(\mathbf{n = 2 6 )}\end{array}$ & $\begin{array}{c}\text { All patients } \\
(\mathbf{n}=63)\end{array}$ \\
\hline $\mathrm{Hb}(\mathrm{g} / \mathrm{dL})$ & $13.90(13.2-15.00)$ & $10.90(10.30-12.30)^{*}$ \\
\hline White cell counts $\left(\times 10^{9} / \mathrm{L}\right)$ & $5.78 \pm 1.59$ & $6.23 \pm 2.10$ \\
\hline Lymphocytes $\left(\times 10^{9} / \mathrm{L}\right)$ & $2.35 \pm 0.75$ & $1.47 \pm 0.60^{*}$ \\
\hline Monocytes $\left(\times 10^{9} / \mathrm{L}\right)$ & $0.25 \pm 0.08$ & $0.38 \pm 0.16^{*}$ \\
\hline Neutrophils $\left(\times 10^{9} / \mathrm{L}\right)$ & $3.03 \pm 1.02$ & $4.14 \pm 1.79^{*}$ \\
\hline Albumin $(\mathrm{g} / \mathrm{dL})$ & $\mathrm{NM}$ & $3.8 \pm 0.4$ \\
\hline $\mathrm{CRP}(\mathrm{mg} / \mathrm{dL})$ & $1.75(0.76-4.70)$ & $5.75(1.90-14.01)^{*}$ \\
\hline Elastase $(\mu \mathrm{g} / \mathrm{L})$ & $28.29(26.03-34.74)$ & $36.11(29.69-50.65)^{*}$ \\
\hline Elastase/Neutrophil ratio & $10.86(7.44-12.12)$ & $8.91(7.43-13.78)$ \\
\hline Lactoferrin $(\mu \mathrm{g} / \mathrm{L})$ & $236.56(193.56-295.03)$ & $239.35(165.64-332.60)$ \\
\hline Lactoferrin/Neutrophil ratio & $72.11(55.52-111.83)$ & $60.32(42.82-99.45)$ \\
\hline
\end{tabular}

Table 1. Haematological data and neutrophil activation markers, for controls and for stage 5 CKD patients. ${ }^{*} p<0.05$, vs controls. NM: not measured. Results are presented as mean \pm standard deviation or as median (interquartile ranges). Hb: Haemoglobin; CRP: C-reactive protein. Adapted from Costa, 2008a.

The haemodialysis procedure, itself, seems to lead to neutrophil activation (Costa, 2008a). By evaluating CKD patients before and after haemodialysis procedure (Costa, 2008b), we found a higher haemoglobin concentration and erythrocyte count after haemodialysis (Table 2). This increase in circulating erythrocytes, has been associated (Dasselaar, 2007) to a

\begin{tabular}{|l|c|c|}
\hline \multirow{2}{*}{} & \multicolumn{2}{|c|}{$\begin{array}{c}\text { Stage 5 CKD Patients } \\
(\mathbf{n = 2 0})\end{array}$} \\
\cline { 2 - 3 } & Before & After \\
\hline $\mathrm{Hb}(\mathrm{g} / \mathrm{dL})$ & $12.10(10.95-12.80)$ & $13.20(11.15-14.60)^{*}$ \\
\hline White cell counts $\left(\times 10^{9} / \mathrm{L}\right)$ & $5.86 \pm 1.51$ & $5.93 \pm 2.19$ \\
\hline Neutrophils $\left(\times 10^{9} / \mathrm{L}\right)$ & $3.82 \pm 1.24$ & $3.97 \pm 1.77$ \\
\hline Monocytes $\left(\times 10^{9} / \mathrm{L}\right)$ & $0.24 \pm 0.38$ & $0.17 \pm 0.12$ \\
\hline Lymphocytes $\left(\times 10^{9} / \mathrm{L}\right)$ & $1.64 \pm 0.69$ & $1.66 \pm 0.64$ \\
\hline Elastase $(\mu \mathrm{H} / \mathrm{L})$ & $36.16(29.71-47.13)$ & $51.69(40.08-71.68)^{*}$ \\
\hline Elastase/Neutrophil ratio & $10.66(7.32-13.54)$ & $14.66(13.34-18.95)^{*}$ \\
\hline Lactoferrin $(\mu \mathrm{g} / \mathrm{L})$ & $198.61(137.81-216.97)$ & $236.56(171.28-363.63)^{*}$ \\
\hline Lactoferrin/Neutrophil ratio & $48.33(33.88-64.31)$ & $60.72(51.81-94.81)^{*}$ \\
\hline CRP $(\mathrm{mg} / \mathrm{dL})$ & $3.06(1.39-5.22)$ & $3.53(1.54-5.56)$ \\
\hline
\end{tabular}

Table 2. Hematological data and neutrophil activation markers for stage 5 CKD patients, before and after haemodialysis procedure. ${ }^{*} p<0.05$, vs before haemodialysis. Results are presented as mean \pm standard deviation or as median (interquartile ranges). $\mathrm{Hb}$ : haemoglobin; CRP: C-reactive protein. Adapted from Costa, 2008b. 
translocation of erythrocytes from the splanchnic circulation (and possibly from the splenic circulation) in order to compensate the hypovolemic stress during dialysis ultrafiltration. We also found, after haemodialysis, an increase in mean cell hemoglobin concentration and a decrease in mean cell volume that could be related to erythrocyte membrane protein loss during the hemodialysis procedure (Costa, 2008b). Markers of neutrophil activation were also found to be increased after haemodialysis. In fact, a decrease in CXCR1 neutrophil expression was observed after the haemodialysis procedure [before haemodialysis: $252.25 \pm$ 45.14 MFI (mean fluorescence intensity) vs after haemodialysis: $239.71 \pm 47.62$ MFI; $p=0.04]$, as well as an increase in elastase and lactoferrin plasma levels (Table 2). The enhanced neutrophil activation state after haemodialysis could result from different mechanisms; namely, complement activation, direct interaction with haemodialysis membrane, and from the passage into the blood of bacterial fragments, such as LPS, from contaminated dialysate through the dialyzer membrane.

\section{Erythrocyte senescence and/or damage}

In stage $5 \mathrm{CKD}$ patients, the erythrocytes are metabolically stressed by the unfavourable plasmatic environment, due to metabolite accumulation; by the high rate of haemoglobin autoxidation, due to the increase in haemoglobin turnover, a physiologic compensation mechanism triggered to compensate anaemia (Lucchi, 2000; Stoya, 2002). The erythrocytes will be further stressed during the haemodialysis procedure. Therefore, the erythrocytes are continuously challenged to sustain haemoglobin in its reduced functional form and to maintain the integrity and deformability of the membrane.

When haemoglobin is denatured, it links to the cytoplasmic pole of band 3, triggering its aggregation and leading to the formation of strictly lipidic portions of the membrane, poorly linked to the cytoskeleton. These cells are, probably, more prone to undergo vesiculation (loss of poorly linked membrane portions) whenever they have to circulate through the haemodialysis membranes or the microvasculature. Vesiculation may, therefore, lead to modifications in the erythrocyte membrane of stage 5 CKD patients (Reliene, 2002; Rocha, 2005).

Erythrocytes that develop intracellular defects earlier during their life span are removed prematurely from circulation (Santos-Silva, 1998; Rocha-Pereira, 2004). The removal of senescent or damaged erythrocytes seems to involve the development of a senescent neoantigen on the membrane surface, marking the cell for death. This neoantigen is immunologically related to band 3 (Kay, 1994). The deterioration of the erythrocyte metabolism and/or of its antioxidant defences may lead to the development of oxidative stress within the cell, allowing oxidation and linkage of denatured haemoglobin to the cytoplasmatic domain of band 3, promoting its aggregation, the binding of natural anti-band 3 autoantibodies and complement activation, marking the erythrocyte for death. The band 3 profile [high molecular weight aggregates (HMWAg), band 3 monomer and proteolytic fragments (Pfrag)] is used in order to differentiate younger, damaged and/or senescent erythrocytes. Older and damaged erythrocytes present with higher HMWAg and lower Pfrag. Younger erythrocytes show reduced HMWAg and higher Pfrag (Santos-Silva, 1998). Several diseases, known as inflammatory conditions, present an abnormal band 3 profile, suggestive of oxidative stress development (Santos-Silva, 1998; Belo, 2002; Rocha-Pereira, 2004). 
Leukocyte activation is part of an inflammatory response, and is an important source of ROS and proteases, both of which may impose oxidative and proteolytic damages to erythrocyte and plasma constituents. Actually, oxidative stress has been reported to occur in stage 5 CKD patients and has been proposed as a significant factor in haemodialysis-related shortened erythrocyte survival.

In literature, there are few reports about the effect of CKD and haemodialysis procedure in erythrocyte membrane protein composition (Matos, 1997; Wu, 1998; Ibrahim, 2002). Studies performed in erythrocytes from stage 5 CKD patients, using cuprophane and polyacrylonitrile dialysis membranes, showed some changes in the membrane proteins, namely, a reduction in spectrin and band 3, and an isolated reduction in band 3, respectively (Sevilhano, 1990; Delmas-Beauvieux, 1995). Wu et al (Wu, 1998) and Ibrahim et al (2002) showed that stage 5 CKD patients presented a median osmotic fragility higher than the controls, and, after the haemodialysis procedure, that osmotic fragility decreased.

Recently, we reported for the first time, changes in the erythrocyte membrane band 3 profile in stage 5 CKD patients. These patients presented a decrease in HMWAg and in HMWAg/band 3 monomer ratio (Fig. 3 and table 3). These changes seem to reflect a younger erythrocyte population; however, CKD presented also a decrease in Pfrag and in Pfrag/band 3 monomer ratio, both suggesting a rise in erythrocyte damage. Thus, it seems that the band 3 profile observed in CKD patients is associated both to an increase in younger erythrocytes and to an increase in damaged erythrocytes (Costa, 2008c). This study also showed that the haemodialysis procedure per se does not lead to an increase in the studied markers of erythrocyte damage. Actually, no differences were found after haemodialysis, in band 3 profile.

\begin{tabular}{|l|c|c|}
\hline & $\begin{array}{c}\text { Controls } \\
\mathbf{( n = 2 6 )}\end{array}$ & $\begin{array}{c}\text { Stage 5 CKD patients } \\
\mathbf{( n = 6 3 )}\end{array}$ \\
\hline HMWAg (\%) & $19.90(15.42-21.12)$ & $15.23(13.38-19.40)^{*}$ \\
\hline Band 3 monomer (\%) & $55.28(53.39-57.41)$ & $61.84(56.87-64.41)^{*}$ \\
\hline Pfrag (\%) & $26.29 \pm 4.78$ & $22.70 \pm 6.01^{*}$ \\
\hline HMWAg/ Band 3 monomer & $0.33 \pm 0.07$ & $0.27 \pm 0.07^{*}$ \\
\hline Pfrag/ Band 3 monomer & $0.48 \pm 0.11$ & $0.38 \pm 0.13^{*}$ \\
\hline
\end{tabular}

${ }^{*} \mathrm{p}<0.05$ vs controls. HMWAg; high molecular weight aggregates; Pfrag: proteolytic fragments. Results are presented as mean \pm standard deviation or as median (interquartile ranges).

Table 3. Band 3 profile for controls and stage 5 CKD patients.

Some changes in erythrocyte membrane protein composition of stage 5 CKD patients using high-flux polysulfone FX-class dialysers of Fresenius, were also observed (Costa, 2008b; Costa, 2008d). A decrease in spectrin was the most significant change (table 4). This reduction in spectrin may account for a poor linkage of the cytoskeleton to the membrane, favoring membrane vesiculation, and, probably, a reduction in the erythrocyte lifespan of 
A

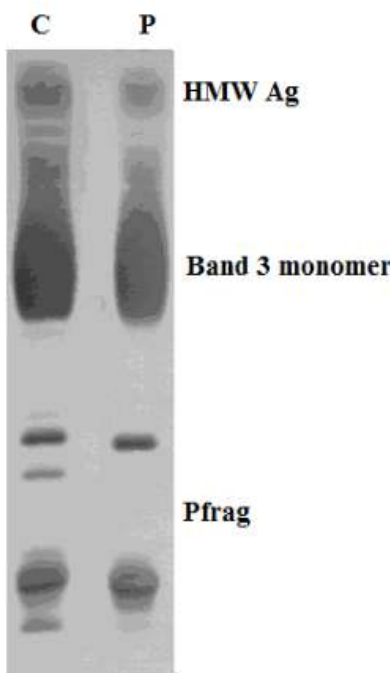

B

C

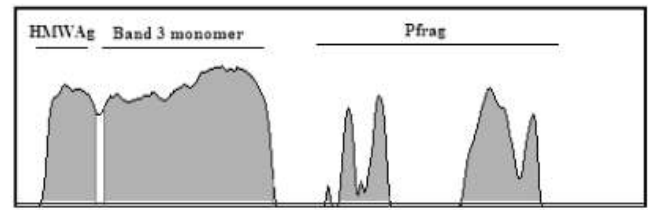

$\mathbf{P}$

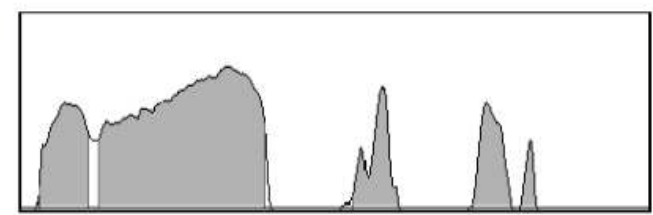

Fig. 3. A- Illustration of two band 3 profiles, one presented by a control (C), and the other presented by a stage 5 CKD patient $(\mathrm{P})$. B- Examples of densitometer tracing of immunoblots for band 3 profile, C- Control; $\mathrm{P}$ - stage 5 CKD patient. HMWAg; high molecular weight aggregates; Pfrag: proteolytic fragments.

\begin{tabular}{|l|c|c|}
\hline & $\begin{array}{c}\text { Controls } \\
(\mathbf{n = 2 6 )}\end{array}$ & $\begin{array}{c}\text { CKD stage 5 Patients } \\
(\mathbf{n = 6 3 )}\end{array}$ \\
\hline Spectrin (\%) & $27.63(26.41-28.79)$ & $24.27(19.39-26.13)^{*}$ \\
\hline Ankyrin (\%) & $6.97 \pm 1.62$ & $6.53 \pm 1.90$ \\
\hline Band 3 (\%) & $38.57 \pm 3.99$ & $39.29 \pm 4.03$ \\
\hline Protein 4.1 (\%) & $7.56 \pm 1.45$ & $7.24 \pm 1.49$ \\
\hline Protein 4.2 (\%) & $5.51 \pm 0.72$ & $5.44 \pm 1.44$ \\
\hline Band 5 (\%) & $6.82 \pm 0.86$ & $6.87 \pm 1.03$ \\
\hline Band 6 (\%) & $5.19 \pm 1.04$ & $6.98 \pm 1.37^{*}$ \\
\hline Band 7 (\%) & $2.20 \pm 0.65$ & $3.32 \pm 1.24^{*}$ \\
\hline Protein 4.1/Spectrin & $0.276 \pm 0.624$ & $0.330 \pm 0.120 \mathrm{a})$ \\
\hline Protein 4.1/Band 3 & $0.192(0.154-0.227)$ & $0.183(0.155-0.208)$ \\
\hline Protein 4.2/Band 3 & $0.149(0.125-0.162)$ & $0.138(0.110-0.163)$ \\
\hline Spectrin/Band 3 & $0.707(0.649-0.822)$ & $0.569(0.512-0.686)^{*}$ \\
\hline Ankyrin/Band 3 & $0.185 \pm 0.585$ & $0.169 \pm 0.057$ \\
\hline Spectrin/ Ankirin & $4.18 \pm 1.07$ & $3.77 \pm 1.84$ \\
\hline
\end{tabular}

Table 4. Erythrocyte membrane protein profile for controls and stage 5 CKD patients.* $p<0.05$, vs controls. Results are presented as mean \pm standard deviation or as median (interquartile ranges). HMWAg; high molecular weight aggregates; Pfrag: proteolytic fragments. Adapted from Costa, 2008d. 
these patients (Reliene, 2002). Significant increases in protein bands 6 and 7 were also observed, which may further reflect an altered membrane protein interaction and destabilization of membrane structure. This membrane destabilization was further strengthened by the significant changes observed for spectrin/band 3 ratio (Costa, 2008b; Costa, 2008d). These membrane protein changes may be due to a higher erythrocyte metabolic stress and/or to changes resulting from the haemodialysis procedure per se.

Studying the effect of the haemodialysis procedure on erythrocyte membrane protein composition in stage 5 CKD patients, by evaluating membrane protein composition before and immediately after haemodialysis procedure (table 5), some trends towards the control profile were observed for some of the membrane proteins - band 3, band 6 and band 7; spectrin showed an even lower value after haemodialysis, and ankyrin, protein 4.1, protein 4.2 and band 5 also presented a trend to decrease. Comparing the ratios before and after haemodialysis, only the ratio spectrin/band 3 showed a statistically significant value, reflecting a vertical membrane protein disturbance.

\begin{tabular}{|l|c|c|}
\hline \multirow{2}{*}{} & \multicolumn{2}{|c|}{$\begin{array}{c}\text { Stage 5 CKD patients } \\
(\mathbf{n}=\mathbf{2 0 )}\end{array}$} \\
\cline { 2 - 3 } & Before haemodialysis & After haemodialysis \\
\hline Spectrin (\%) & $25.58(24.10-27.07)$ & $24.47(22.31-26.95)^{*}$ \\
\hline Ankyrin (\%) & $6.39 \pm 1.55$ & $6.23 \pm 1.28$ \\
\hline Band 3 (\%) & $38.10 \pm 3.78$ & $41.13 \pm 2.44^{*}$ \\
\hline Protein 4.1 (\%) & $6.48 \pm 1.60$ & $6.39 \pm 1.69$ \\
\hline Protein 4.2 (\%) & $4.34 \pm 0.99$ & $4.84 \pm 1.04$ \\
\hline Band 5 (\%) & $6.56 \pm 0.91$ & $6.71 \pm 0.59$ \\
\hline Band 6 (\%) & $6.46 \pm 0.87$ & $6.17 \pm 1.15$ \\
\hline Band 7 (\%) & $2.09 \pm 0.43$ & $2.37 \pm 0.34$ \\
\hline Protein 4.1/Spectrin & $0.243 \pm 0.070$ & $0.251 \pm 0.081$ \\
\hline Protein 4.1/Band 3 & $0.170(0.138-0.206)$ & $0.163(0.121-0.202)$ \\
\hline Protein 4.2/Band 3 & $0.114(0.101-0.133)$ & $0.118(0.101-0.147)$ \\
\hline Spectrin/Band 3 & $0.685(0.626-0.796)$ & $0.647(0.566-0.689)^{*}$ \\
\hline Ankyrin/Band 3 & $0.171 \pm 0.049$ & $0.152 \pm 0.330$ \\
\hline Spectrin/ Ankirin & $4.48 \pm 1.361$ & $4.45 \pm 1.49$ \\
\hline
\end{tabular}

* $p<0.05$, vs before haemodialysis. Results are presented as mean \pm standard deviation or as median (interquartile ranges). HMWAg; high molecular weight aggregates; Pfrag: proteolytic fragments. Adapted from Costa, 2008b.

Table 5. Erythrocyte membrane protein profile for stage 5 CKD patients, before and immediately after haemodialysis procedure.

Haemodialysis procedure seems to have an important role in the changes observed for erythrocyte membrane protein composition; however, their exact origin(s) are not yet fully understood. An hypothesis is that the increased plasma levels of elastase found in stage 5 
CKD patients could induce changes in erythrocyte membrane proteins, leading to a decrease in erythrocyte lifespan, and, consequently, to an increase in the degree of the anaemia. This hypothesis was tested (Pereira, 2011), by performing some in vitro assays using erythrocytes from 18 stage 5 CKD patients (10 responders and 8 non-responders to recombinant human erythropoietin therapy) and from 8 healthy controls; erythrocyte suspensions in phosphate buffered saline, $\mathrm{pH} 7.4$, were incubated at $37^{\circ} \mathrm{C}$, under gentle rotation, in the presence of $0.03,0.1$ and $0.5 \mu \mathrm{g} / \mathrm{mL}$ of neutrophil elastase. These assays used erythrocytes collected before and immediately after the haemodialysis procedure.
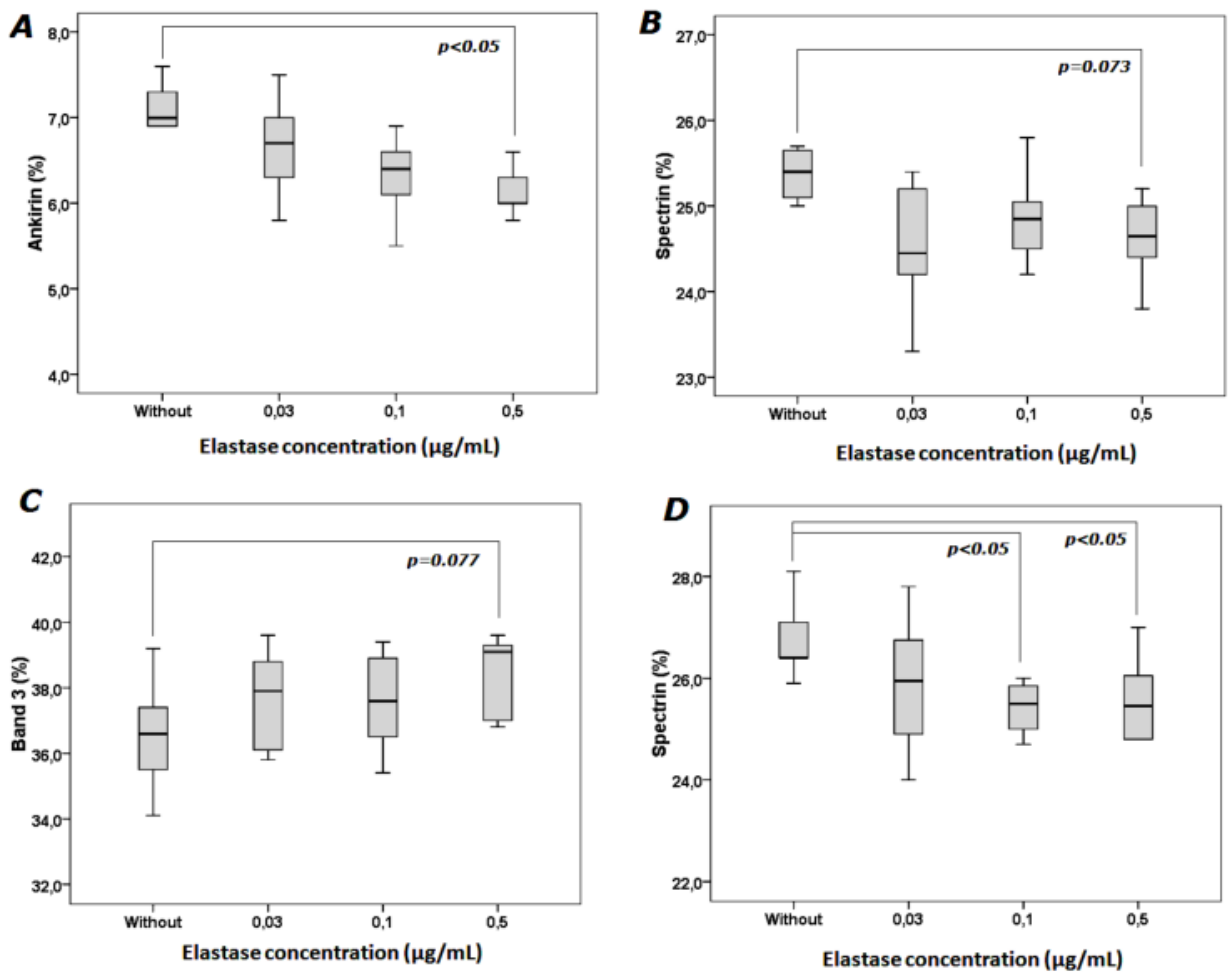

Fig. 4. Changes in ankyrin (A), spectrin (B) and band 3 (C) observed for erythrocytes from responder stage 5 CKD patients before haemodialysis, when incubated without and with elastase; changes in spectrin presented by erythrocytes from non-responder stage 5 CKD patients before haemodialysis, when incubated without and with elastase (D). Adapted from Pereira, 2011.

No significant differences were found between the protein composition of the erythrocyte membranes from healthy controls and from stage 5 CKD patients, when their erythrocytes, collected after the haemodialysis procedure, were incubated without and with different elastase concentrations. However, the erythrocytes from stage 5 CKD patients, collected before the haemodialysis procedure, showed some susceptibility to elastase; the erythrocytes from responders stage 5 CKD patients, incubated with $0.5 \mu \mathrm{g} / \mathrm{mL}$ of elastase showed a significant decrease in ankyrin [7.0 (6.5-7.5\%) vs $6.0(5.9-6.5 \%), p=0.024]$, and 
trends towards a decrease in spectrin [25.6 (25.1-26.9\%) vs $24.7(24.4-25.6 \%), p=0.073)$ and an increase in band 3 [36.6 (34.8-37.6\%) vs 39.1 (36.9-39.4\%), p=0.077), as compared with erythrocytes incubated without elastase. Similar changes were found for the erythrocytes incubated with $0.1 \mu \mathrm{g} / \mathrm{mL}$ of elastase. In non-responders stage 5 CKD patients, the erythrocytes incubated with 0.1 and $0.5 \mu \mathrm{g} / \mathrm{mL}$ of elastase, showed a significant decrease in spectrin [25.5 (24.9-25.9\%) and $25.3(24.8-26.2 \%)$, respectively vs $26.4(26.0-27.3 \%), p=0.011$ for both], as compared to erythrocytes incubated without elastase (Fig. 4).

These findings suggest that the erythrocytes from stage 5 CKD patients, before the haemodialysis procedure, are more susceptible to the proteolytic action of elastase upon the membrane. Considering that after the haemodialysis procedure the composition of the erythrocyte membrane from stage 5 CKD patients did not change, it seems that the more susceptible erythrocytes were removed during the haemodialysis procedure. Moreover, the release of neutrophil activation products, such as elastase, during haemodialysis may contribute to the removal of the more damaged cells, by enhancing membrane protein changes.

\section{Other pathologies associated with neutrophil activation and erythrocyte damage}

Several physiological (physical exercise, pregnancy) and pathological (hereditary spherocytosis, cardiovascular disease, preeclampsia, psoriasis) conditions presenting with neutrophilic leukocytosis have been associated to an altered erythrocyte membrane protein composition and to other changes reflecting erythrocyte damage. Moreover, they have been associated to increased neutrophil activation products, suggesting that leukocyte activation may trigger injuries in the neighboring erythrocytes.

In Hereditary Spherocytosis (HS), mutations in genes encoding for some membrane proteins - band 3, spectrin, protein band 4.2 and ankyrin - may result in their partial or inaccurate assembly to the membrane. Deficiencies in one or more of those proteins cause a decrease in membrane stability that, in turn, leads to loss of membrane surface area through membrane vesiculation. By losing membrane vesicles, the cell will become spherocytic and the membrane more rigid, triggering the sequestration of cell in the spleen and, therefore, the reduction of the erythrocyte lifespan and the development of anemia (Mohandas \& Gallagher, 2008).

Two distinct pathways lead to the reduction in membrane surface area: i) deficiencies in spectrin, ankyrin, or protein 4.2 reduce the density of the membrane cytoskeleton, causing a weaker linkage to the lipid bilayer, favoring the loss of membrane vesicles containing lipids and band 3; ii) deficiency in band 3 favors the development of band 3 deficient areas in the membrane, with loss of the lipid-stabilizing effect of band 3, and therefore, the release of band 3-free microvesicles, from the membrane (Iolascon, 2003; Perrotta, 2008). In a recent work by our group (Rocha, 2010), studying 160 HS patients, the analysis of erythrocyte membrane protein profile showed that 109 patients presented a primary deficiency in band 3, 35 patients a primary ankyrin deficiency, 14 patients an isolated deficiency in spectrin and 2 patients an isolated deficiency in protein 4.2. Furthermore, severe HS patients presented with higher neutrophil count and higher levels of TNF- $\alpha$, IFN- $\gamma$, elastase, lactoferrin and ferritin. Our data show HS as a disease linked to enhanced erythropoiesis that is disturbed in the more severe forms, to which inflammation, at least in part, seems to contribute. 
Patients with cardiovascular disease, namely, with recent myocardial infarction (within the last $48 \mathrm{~h}$ ), survivors for at least 3 months of myocardial infarction and hypertensive individuals, presented besides a neutrophilic leukocytosis a different band 3 profile, with higher values of HMWAg and lower values of band 3 monomer and of Pfrag (Santos-Silva, 1995). Ischemic stroke patients presented the same altered band 3 profile, associated with increased plasma levels of leukocyte activation products - elastase and lactoferrin - when compared with controls (Santos-Silva, 1998).

Band 3 profile in normal pregnancy in the first trimester of pregnancy, when compared with healthy controls, presented significantly reduced HMWAg and increased Pfrag. Comparing the third with the first trimester, a significant reduction in band 3 and a significant rise in Pfrag was also described. These results suggest band 3 profile as a marker of erythrocyte changes in normal pregnancy, which are independent of the 'physiological anemia' of pregnancy. These changes suggest an increase in damaged erythrocytes, but also an increase in younger erythrocytes in the maternal circulation. We also found alterations in the markers of erythrocyte damage in preeclampsia, in both umbilical cord blood and maternal circulation. In preeclamptic pregnancies in the third trimester of gestation, a significantly higher level of elastase and a significantly higher elastase to neutrophil ratio was also described, suggesting an increased neutrophil activation in these patients (Belo, 2002; Belo, 2003).

Psoriasis was also associated with plasma neutrophil activation, showing increased plasma levels of elastase and lactoferrin, associated with alterations in band 3 profile (Rocha-Pereira, 2004).

\section{Conclusions}

Stage $5 \mathrm{CKD}$ is associated with an altered structure of erythrocyte membrane proteins, which may be due to the disease itself and/or to the interaction of blood cells with haemodialysis membranes. Haemodialysis procedure seems to contribute to a disturbance in the erythrocyte membrane protein structure, as showed by the significant reduction in spectrin, the most striking change observed.

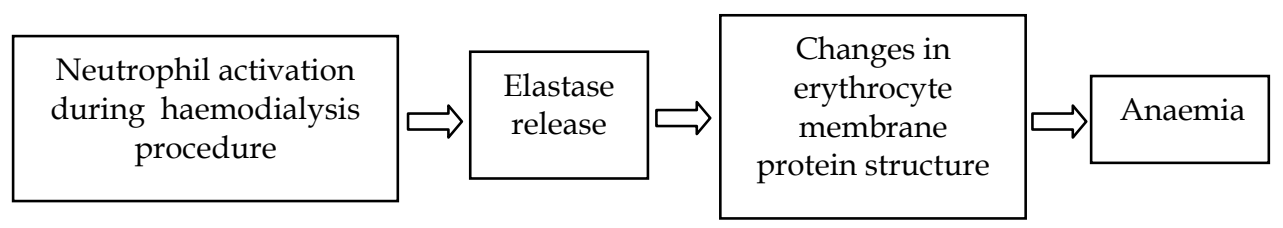

Fig. 5. In stage 5 CKD patients, the increased plasma levels of elastase can induce changes in erythrocyte membrane proteins, leading to a decrease in the erythrocyte lifespan and, consequently, to increase the degree of anaemia in these patients.

Moreover, stage 5 CKD patients under haemodialysis also present higher elastase plasma levels, which might reflect the rise in neutrophils and the enhanced inflammatory process found in these patients. Haemodialysis procedure seems to be associated with neutrophil activation, with subsequent elastase release that seems to induce changes in the erythrocyte membrane protein composition, probably contributing to a decrease in the erythrocyte halflife, and, therefore to the anemia found in stage 5 CKD patients (Fig. 5). 


\section{Acknowledgments}

This work was supported by national funds - "Fundação Portuguesa para a Ciência e Tecnologia" (FCT: PIC/IC/83221/2007) and co-financed by FEDER (FCOMP-01-0124FEDER-008468).

\section{References}

An, X.; Mohandas, N. (2008). Disorders of red cell membrane. Br J Haematol, vol. 141, pp. 367-375, ISSN 0007-1048

Bárány, P. (2001). Inflammation, serum C-reactive protein, and erythropoietin resistance. Nephrol Dial transplant, vol. 16, pp. 224-227, ISSN 0931- 0509

Baynes, R.; Bezwoda, W.; Bothwell, T.; Khan, Q.; Mansoor, N. (1986). The non immune inflammatory response: serial changes in plasma iron, iron binding capacity, lactoferrin, ferritin and C reactive protein. Scan J Clin Lab Invest, vol. 46, pp. 695-704, ISSN 0036-5513

Belo, L.; Rebelo, I.; Castro, E.M.; Catarino, C.; Pereira-Leite, L.; Quintanilha, A.; Santos-Silva, A. (2002). Band 3 as a marker of erythrocyte changes in pregnancy. Eur J Haematol, vol. 69, pp.145-151, ISSN 0902- 4441

Belo, L.; Santos-Silva, A.; Caslake, M.; Cooney, J.; Pereira-Leite, L.; Quintanilha, A.; Rebelo, I. (2003). Neutrophil activation and C-reactive protein concentration in preeclampsia. Hypertens Pregnancy, vol. 22, pp.129-141, ISSN 1064-1955

Brinkmann, V.; Reichard, U.; Goosmann, C.; Fauler, B.; Uhlemann, Y.; Weiss, D.S.; Weinrauch, Y. \& Zychlinsky, A. (2004). Neutrophil extracellular traps kill bacteria. Science, vol. 303, pp.1532-1535, ISSN 0036-8075

Costa, E.; Rocha, S.; Rocha-Pereira, P.; Nascimento, H.; Castro, E.; Miranda, V.; Faria, M.S.; Loureiro, A.; Quintanilha, A.; Belo, L. \& Santos-Silva, A. (2008a). Neutrophil activation and resistance to recombinant human erythropoietin therapy in hemodialysis patients. Am J Nephrol, vol. 28, pp. 935-940, ISSN 1046-6673

Costa, E.; Rocha, S.; Rocha-Pereira, P.; Castro, E.; Miranda, V.; Sameiro-Faria, M.; Loureiro, A.; Quintanilha, A.; Belo, L. \& Santos-Silva, A. (2008b). Changes in red blood cells membrane protein composition during hemodialysis procedure. Ren Fail, vol. 30, pp. 971-975, ISSN 0886- 022

Costa, E.; Rocha, S.; Rocha-Pereira, P.; Castro, E.; Miranda, V.; Sameiro-Faria, M.; Loureiro, A.; Quintanilha, A.; Belo, L. \& Santos-Silva, A. (2008c). Band profile as a marker of erythrocyte changes in chronic kidney disease patients. The Open Clinical Chemistry Journal, vol. 1, pp. 57-63, ISSN 1874-2416

Costa, E.; Rocha, S.; Rocha-Pereira, P.; Castro, E.; Miranda, V.; Sameiro-Faria, M.; Loureiro, A.; Quintanilha, A.; Belo, L. \& Santos-Silva, A. (2008d). Alterated erythrocyte membrane protein composition in chronic kidney disease stage 5 patients under haemodialysis and recombinant human erythropoietin therapy. Blood Purif, vol. 26, pp. 267-273, ISSN 0253-5068

Dasselaar, J.J.; Hooge, M.N..; Pruim, J.; Nijnuis, H.; Wiersum, A.; Jong, P.E.; Huisman, R.M.; Franssen, C.F.M. (2007). Relative blood volume changes underestimated total blood volume changes during hemodialysis. Clin J Am Soc Nephrol 2:669-674, ISSN 15559041 
Delmas-Beauvieux, M.C.; Combe, C.; Peuchant, E.; Carbonneau, M.A.; Dubourg, L.; de Précigout, V.; Aparicio, M.; Clerc, M. (1995). Evaluation of red blood cell lipoperoxidation in hemodialysed patients during erythropoietin therapy supplemented or not with iron. Nephron, vol. 69, pp. 404-410, ISSN 0028-2766

Fitch, P.M.; Roghanian, A.; Howie, S.E.M. \& Sallenave, J.M. (2006). Human neutrophil elastase inhibitors in innate and adaptive immunity. Biochemical Society Transactions, vol. 34, pp. 279-282, ISSN 0300-5127

Gallagher, P.G. (2005). Red cell membrane disorders. Hematology. Am Soc Hematol Educ Program, pp. 13-18, ISSN 1520-4383

Halliwell, B.; Gutteridge, J.M.C. (1990). The antioxidants of human extracelular fluids. Arch Biochem Biophys, vol. 280, pp. 1-8, ISSN 0003- 9861

Harlan, J.M. (1985). Leukocyte-endothelial interactions. Blood, vol. 65, pp. 513- 525, ISSN 0006-4971

Ibrahim, F.F.; Ghannam, M.M.; Ali, F.M. (2002). Effect of dialysis on erythrocyte membrane of chronically hemodialyzed patients. Renal failure, vol. 24, pp. 779-790, ISSN 0886$022 X$

Iolascon, A.; Perrota, S.; Steward, G.W. (2003). Red blood cell membrane defects. Rev Clin Exp Hematol, vol. 7, pp. 22-56, ISSN 1127-0020

Kay, M.M.; Wyant, T. \& Goodman, J. (1994). Autoantibodies to band 3 during aging and disease and aging interventions. Ann N Y Acad Sci, vol. 719, pp. 419- 447, ISSN 0077-8923

Levay, P.F.; Viljoen, M. (1995). Lactoferrin: a general review. Haematologica, vol. 80, pp. 252267, ISSN 0390-6078

Ley, K.; Laudanna, C.; Cybulsky, M.I. \& Nourshargh, S. (2007). Getting to the site of inflammation: the leukocyte adhesion cascade updated. Nature Reviews Immunology, vol. 7, pp. 678-689, ISSN 1474-1733

Locatelli, F.; Aljama, P.; Barany, P.; Canaud, B.; Carrera, F.; Eckardt, K.U.; Horl, W.H.; Macdougal, I.C.; Macleod, A.; Wiecek, A. \& Cameron, S. (2004a). European Best Practice Guidelines Working Group. Revised European best practice guidelines for the management of anemia in patients with chronic renal failure. Nephrol Dial Transplant, vol. 19, Suppl 2, pp. ii1-ii47, ISSN 0931- 0509

Lucchi, L.; Bergamini, S.; Botti, B.; Rapanà, R.; Ciuffreda, A.; Ruggiero, P.; Ballestri, M.; Tomasi, A. \& Albertazzi, A. (2000). Influence of different hemodialysis membrane on red blood cell susceptibility of oxidative stress. Artif Organs, vol. 24, pp. 1-6, ISSN 1525-1594

Martos, M.R.; Hendry, B.M.; Rodrígues-Puyol, M.; Dwight, J.; Díez-Marqués, M.L.; Rodríguez-Puyol, D. (1997). Haemodialyser biocompatibility and erythrocyte struture and function. Clin Chim Acta, vol. 265, pp. 235-246, ISSN 0009-8981

Medina, A.; Ellis, C.; Levitt, M.D. (1994). Use of alveolar carbon monoxide measurements to assess red blood cell survival in hemodialysis patients. Am J Hematol, vol. 46, pp.91-94, ISSN 0361-8609

Miyoshi, I.; Saito, T.; Bandobashi, K.; Ohtsuki, .; Taguchi, H. (2006). Concomitant deposition of aluminum and iron in bone marrow trabeculae. Intern Med, vol. 45, pp. 117-118, ISSN 0365-4362

Mohandas, N.; Gallagher, P.G. (2008). Red Cell membrane: past, present, and future. Blood, vol. 112, pp. 3939-3948 
Muller, W.A. (1999). Leukocyte-endothelial cell adhesion molecules in transendothelial migration, pp. 585-592, In: Inflammation: basic principles and clinical correlates, Gallin, J.I.; Snyderman, R.; Fearon, D.T.; Haynes, B.F. \& Nathan C. (Ed.), 585-592, Lippincott Williams and Wilkins, ISBN 978-039-7517-59-6, Philadelphia, USA

Olofsson, T.; Olsson, I.; Venge, P.; Elgefors, B. (1977). Serum myeloperoxidase and lactoferrin in neutropenia. Scand J Haematol, vol. 18, pp. 73-80, ISSN 0036-553X

Pay, S.; Musabak, U.; Simşek, I.; Pekel, A.; Erdem, H.; Dinç, A. \& Sengül, A. (2006). Expression of CXCR-1 and CXCR-2 chemokine receptors on synovial neutrophils in inflammatory arthritides: does persistent or increasing expression of CXCR-2 contribute to the chronic inflammation or erosive changes? Joint Bone Spine, vol. 73, pp. 691-6, ISSN 1778-7254

Pereira, R.; Costa, E.; Gonçalves, M.; Miranda, V.; Sameiro-Faria, M.; Quintanilha, A.; Belo, L.; Lima, M. \& Santos-Silva, A. (2010). Neutrophil and monocyte activation in chronic kidney disease patients under hemodialysis and its relationship with resistance to recombinant human erythropoietin and to the hemodialysis procedure. Hemodial Int, vol. 14, pp. 295-301, ISSN 1492-7535

Pereira, R.; Rocha, S.; Borges, A.; Nascimento, H.; Reis, F.; Miranda, V.; Sameiro-Faria, M.; Quintanilha, A.; Belo, L.; Costa, E.; Santos-Silva, A. (2011). Elastase release during the hemodialysis procedure seems to induce changes in red blood cell membrane proteins. Hemodial Int, in press, ISSN 1492-7535

Perrota, S.; Gallagher, P.G.; Mohandas, N. (2008). Hereditary spherocytosis. Lancet, vol. 372, pp. 1411-1426, ISSN 0140-6736

Pisoni, R.L.; Bragg-Gresham, J.L.; Young, E.W.; Akizawa, T.; Asano, Y.; Locatelli, F.; Bommer, J.; Cruz, J.M.; Kerr, P.J.; Mendelssohn, D.C.; Held, P.J.; Port, F.K. (2004). Anemia management and outcomes from 12 countries in the dialysis outcomes and practice patterns study (DOPPS). Am J Kidney Dis, vol. 44, pp. 94-111, ISSN 02726386

Reliene, R.; Marini, M.; Zanella, A.; Reinhart, W.H.; Ribeiro, M.L.; del Giudice, E.M.; Perrotta, S.; Ionoscon, A.; Eber, S. \& Lutz, H.U. (2002). Splenectomy prolongs in vivo survival of erythrocytes differently in spectrin/ankyrin- and band 3-deficient hereditary spherocytosis. Blood, vol. 100, pp. 2208-2215, ISSN 0006-4971

Rocha, S.; Costa, E.; Rocha-Pereira, P.; Ferreira, F.; Cleto, E.; Barbot, J.; Quintanilha, A.; Belo, L.; Santos-Silva, A. (2010). Erythrocyte membrane protein destabilization versus clinical outcome in 160 Portuguese Hereditary Spherocytosis patients.Br J Haematol, vol. 149, pp.785-794, ISSN 00071048

Rocha, S.; Rebelo, I.; Costa, E.; Catarino, C.; Belo, L.; Castro, E.M.B.; Cabeda, J.M.; Barbot, J.; Quintanilha, A. \& Santos-Silva, A. (2005). Protein deficiency balance as a predictor of clinical outcome in hereditary spherocytosis. Eur J Haematol, vol. 74, pp. 374-80, ISSN 0902- 4441

Rocha-Pereira, P.; Santos-Silva, A.; Rebelo, I.; Figueiredo, A.; Quintanilha, A. \& Teixeira, F. (2004). Erythrocyte damage in mild and severe psoriasis. Br J Dermatology, vol. 150, pp. 232-44, ISSN 0007-0963

Roos, D.; Van Bruggen, R. \& Meischl, C. (2003). Oxidative killing of microbes by neutrophils. Microbes Infect, vol. 5, pp. 1307-1315, ISSN 1286-4579

Saito, N.; Takemori, N.; Hirai, K.; Onodera, R.; Watanabe, S.; Naiki, M. (1993). Ultrastructural localization of lactoferrin in the granules other than typical 
secondary granules of human neutrophils. Human Cell, vol. 6, pp. 42-48, ISSN 09147470

Santos-Silva, A.; Castro, E.; Teixeira, N.; Guerra, F.; Quintanilha, A. (1995). Altered erythrocyte membrane band 3 profile as a marker in patients at risk for cardiovascular disease. Atherosclerosis, vol. 116, pp.199-209, ISSN 0021-9150

Santos-Silva, A.; Castro, E.M.B.; Teixeira, N.A.; Guerra, F.C. \& Quintanilha, A. (1998). Erythrocyte membrane band 3 profile imposed by cellular aging, by activated neutrophils and by neutrophilic elastase. Clin Chim Acta, vol. 275, pp.185-196, ISSN 0009-8981

Sevillano G, Rodrígues-Puyol M, Martos R, Duque I, Lamas S, Diez-Marques ML, Lúcio J, Rodriguez-Puvol D. (1990). Cellulose acetato membrane improves some aspects of red blood cell function in hemodialysis patients. Nephrol Dial Transplant, vol. 5, pp. 497-499, ISSN 0931- 0509

Sherry, B.; Dai, W.W.; Lesser, M.L. \& Trachtman, H. (2008). Dysregulated chemokine receptor expression and chemokine-mediated cell trafficking in pediatric patients with ESRD. Clin J Am Soc Nephrol, vol. 3, pp. 397-406, ISSN 1555-9041

Stoya, G.; Klemm, A.; Baumann, E.; Vogelsang, H.; Ott, U.; Linss, W. \& Stein, G. (2002). Determination of autofluorescence of red blood cells (RBCs) in uremic patients as a marker of oxidative damage. Clin Nephrol, vol. 58, pp.198-204, ISSN 0301- 0430

Sullivan, G.W.; Sarembock, I.J. \& Linden, J. (2000). The role of inflammation in vascular diseases. J Leukoc Biol, vol. 67, pp. 591-602, ISSN 0741-5400

Witko-Sarsat, V.; Rieu, P.; Descamps-Latscha, B.; Lesavre, P.; Halbwachs-Mecarelli, L. (2000). Neutrophils: molecules, functions and pathophysiological aspects. Lab Invest, vol. 80, pp. 617-653, ISSN 0023-6837

Wu, S.G.; Jeng, F.R.; Wei, S.Y.; Su, C.Z.; Chung, T.; Chang, W.J.; Chang, H.W. (1998). Red blood cell osmotic fragility in chronically hemodialyed. Nephron, vol.78, pp. 28-32, ISSN 0028-2766 


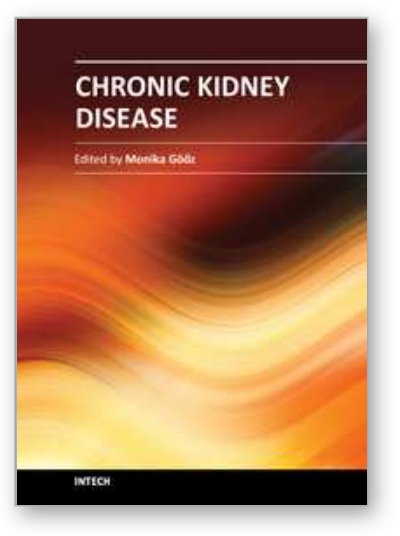

\author{
Chronic Kidney Disease \\ Edited by Prof. Monika Göőz
}

ISBN 978-953-51-0171-0

Hard cover, 444 pages

Publisher InTech

Published online 16, March, 2012

Published in print edition March, 2012

Chronic kidney disease is an increasing health and economical problem in our world. Obesity and diabetes mellitus, the two most common cause of CKD, are becoming epidemic in our societies. Education on healthy lifestyle and diet is becoming more and more important for reducing the number of type 2 diabetics and patients with hypertension. Education of our patients is also crucial for successful maintenance therapy. There are, however, certain other factors leading to CKD, for instance the genetic predisposition in the case of polycystic kidney disease or type 1 diabetes, where education alone is not enough.

\title{
How to reference
}

In order to correctly reference this scholarly work, feel free to copy and paste the following:

Elísio Costa, Luís Belo and Alice Santos-Silva (2012). Neutrophil Activation and Erythrocyte Membrane Protein Composition in Stage 5 Chronic Kidney Disease Patients, Chronic Kidney Disease, Prof. Monika Göőz (Ed.), ISBN: 978-953-51-0171-0, InTech, Available from: http://www.intechopen.com/books/chronic-kidneydisease/neutrophil-activation-and-erythrocyte-membrane-protein-composition-in-stage-5-chronic-kidneydisease

\section{INTECH}

open science | open minds

\section{InTech Europe}

University Campus STeP Ri

Slavka Krautzeka 83/A

51000 Rijeka, Croatia

Phone: +385 (51) 770447

Fax: +385 (51) 686166

www.intechopen.com

\section{InTech China}

Unit 405, Office Block, Hotel Equatorial Shanghai

No.65, Yan An Road (West), Shanghai, 200040, China 中国上海市延安西路65号上海国际贵都大饭店办公楼 405 单元

Phone: +86-21-62489820

Fax: $+86-21-62489821$ 
(C) 2012 The Author(s). Licensee IntechOpen. This is an open access article distributed under the terms of the Creative Commons Attribution 3.0 License, which permits unrestricted use, distribution, and reproduction in any medium, provided the original work is properly cited. 